\title{
An invitation to the Cincinnati Conference
}

We would like to invite you to join us in Cincinnati, April 5-8, 1989, for ACRL's Fifth National Conference, "Building on the First Century." We hope you will be there with your friends and colleagues to learn, to celebrate, and to build for the future.

You can celebrate four birthdays at the conference! The ALA College Library Section is 100 years old, ACRL, College and Research Libraries, and C $b R L$ News are all 50 years old, and Choice is 25 . You can join your colleagues in honoring many of the people whose contributions have brought us to this year of milestones and preparing ourselves for the achievements of the future.

This conference offers a wealth of opportunities for professional growth and enrichment. You will find that papers and programs have been planned to appeal to your diverse interests. This is the first time that ACRL's national conference has featured programs in addition to papers, and the response to this has been tremendous! You will find many topics and formats from which to choose. In addition, several major speakers will be featured including: Robert Caro, the Pulitzer Prize-winning author; Samuel Proctor, a nationally known and respected educator and leader; Mary Anne Dolan, a syndicated columnist and television commentator based in Los Angeles; and Ed Holley, our own Academic or Research Librarian of the Year 1988.
Begin your stay in Cincinnati with the preconference courses (April 3-4); attend our night out at the Reds-Dodgers game (April 5); enjoy the Conference Reception and the many other activities which are planned. Explore the delights of the Queen City where you can go Highbrow, Soul or Rock; be an athletic spectator, nature lover or gourmet. Then conclude your visit by attending the post-conference on research (April 8-9.)

Please join us in Cincinnati. Come to learn, to meet your colleagues and to celebrate with those who best understand you and your needs-the Association of College and Research Libraries. Take your pen in hand and fill in the registration form today. It's a decision you will be glad you made! Sincerely,

\section{Martha Alexander Bowman \\ Conference Co-chair \\ University Librarian \\ University of Louisville \\ Evan Ira Farber \\ Conference Co-chair \\ Librarian \\ Earlham College}

P.S. - You will save $\$ 30$ if you register by March 6 , 1989 !

\section{National Conference Executive Committee}

Co-Chair: Martha Alexander Bowman, University Librarian, University of Louisville, Lou isville, KY 40292.

Co-Chair: Evan Ira Farber, Librarian, Earlham College, Richmond, IN 47374.

Contributed Papers Chair: Jan Fennell, Director of Libraries, Georgia College, Milledgeville, GA 31061 .

Local Arrangements Chair: Mary Ellen Elsbernd, Collection Development Librarian, North- ern Kentucky University, Highland Heights, KY 41076.

Program Chair: Jordan M. Scepanski, California State University, Long Beach, CA 90840.

Conference Assistant: Anne Kearney, Assistant to the University Librarian, University of Louisville, Louisville, KY 40292.

Exhibits Manager: Sandy Donnelly, ACRL/ALA Headquarters, $50 \mathrm{E}$. Huron St., Chicago, IL 60611 . 
ACRL Staff Liaison: Cathleen Bourdon, ACRL/ALA Headquarters, 50 E. Huron St., Chicago, IL 60611 .
ACRL Executive Director: JoAn S. Segal, ACRL/ALA, 50 E. Huron St., Chicago, IL 60611.

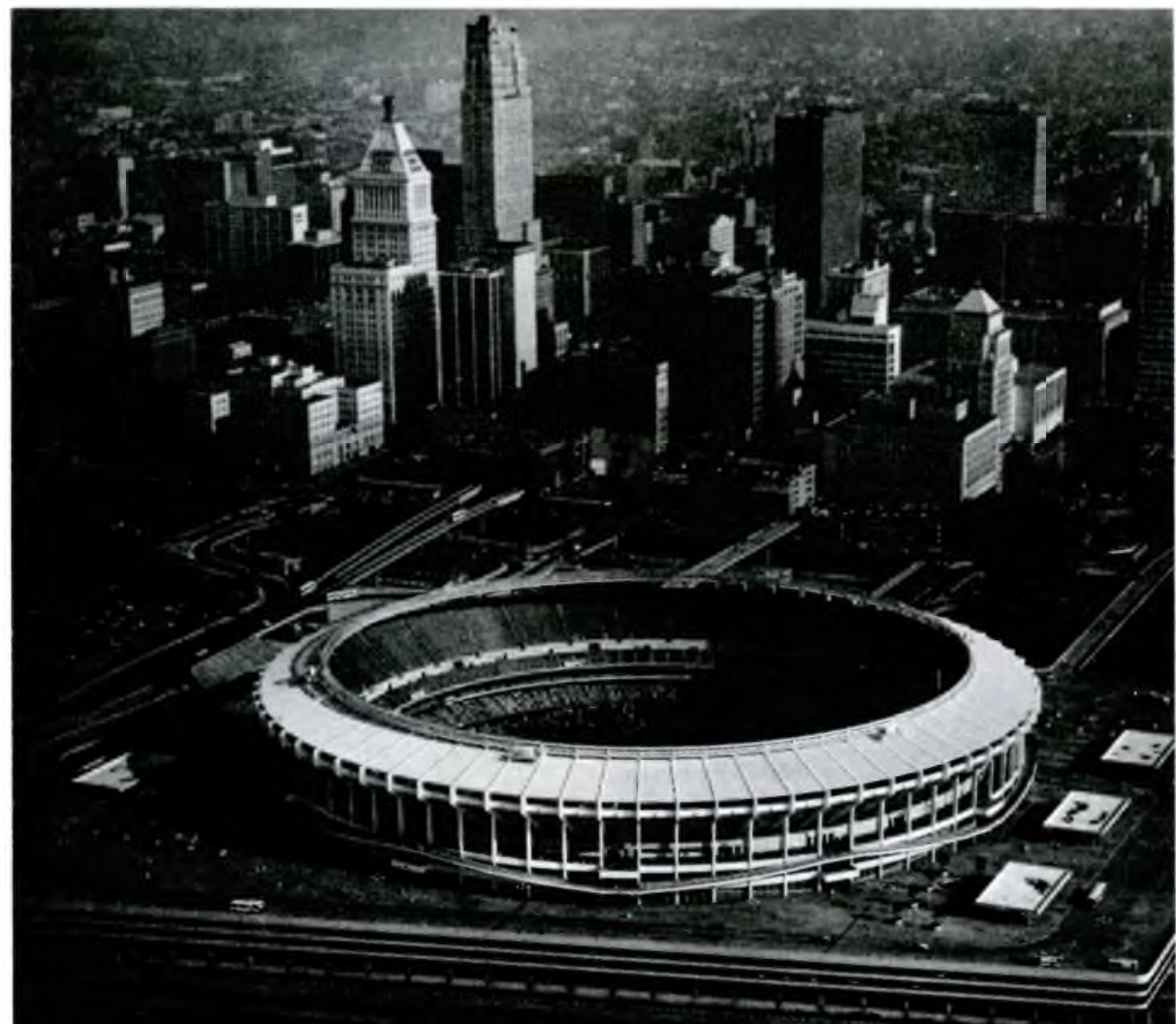

다요

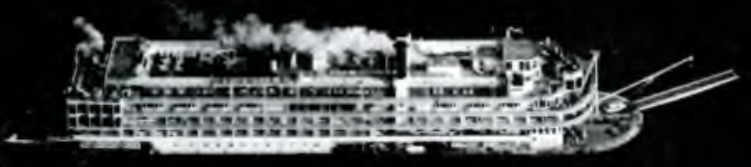

The majestic steamboat Mississippi Queen cruises past her home port of Cincinnati and its Riverfront Stadium, home of the Cincinnati Reds and Cincinnati Bengals. 


\section{REESEARCH PUBLICATIONS}

\section{Guaranteed availability, when you want them.}

Journals of Science, Technology, and Medicine in microform.

Every title filmed and delivered - from the first issue forward. Current subscriptions are delivered within three months of the end of the volume year, and availability of all backfiles is guaranteed. For complete title listings and prices, call 1-800-RRACH-RP (1-800-732-2477) now. From Connecticut, Alaska and Canada, call collect (203) 397-2600.

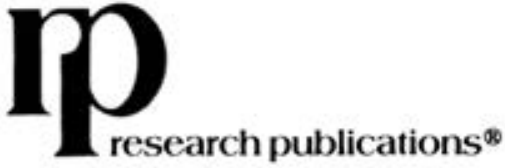

\section{Research Publications, Inc. 12 Lunar Drive/Drawer AF Woodbridge, CT 06525 (203) 397-2600}

\section{LOOKING FOR A JOB?}

ACRL's Fast Job Listing Service brings you job notices four weeks before they appear in College \& Research Libraries News. This monthly bulletin also contains job postings that, because of narrow application deadlines, do not appear in C\&RLNews.

The Fast Job Listing Service is sent to subscribers by first-class mail the first week of every month. You can be a step ahead of other job applicants by seeing position descriptions very shortly after they are received in our office.

Subscriptions to the Fast Job Listing Service are for a period of six months - by that time we hope you have found the job you're looking for! The cost is $\$ 10$ for ACRL members and $\$ 15$ for non-members.

You may use the form below to enter your subscription.

YES! I want to see job notices as quickly as possible by subscribing to ACRL's Fast Job Listing Service.

I am a member of ACRL and am enclosing \$10.

I am not a member of ACRL and am enciosing $\$ 15$.

NAME:

ADDRESS:

CITY/STATE/ZIP:

Please make checks payable to ACRL/ALA and send to the Fast Job Listing Service, ACRL/ALA, 50 E. Huron Street, Chicago, IL 60611. 